KS. WALDEMAR GRACZYK* - WARSZAWA

\title{
STARE DRUKI TZW. KARMELITANA W ZBIORACH BIBLIOTEKI KLASZTORU W CZERNEJ ${ }^{1}$
}

Zakon karmelitów bosych, powstały w Hiszpanii w wyniku wielkiej reformy Kościoła przeprowadzonej w XVI wieku, prawie natychmiast włączył się w nurt odnowy potrydenckiej². Przejawiało się to między innymi w bogatej literaturze teologicznej, uważano bowiem, że ,nie można lepiej służyć Kościołowi i jego sprawom, jak w oparciu o mocne zręby nauki św. Tomasza z Akwinu"3.

Powstały w XVII wieku klasztor-erem karmelitów bosych w Czernej od początku swego istnienia gromadził księgi związane z historią, duchowością karmelitańską, oraz z prawodawstwem tego zakonu. Wynikało to z faktu, że karmelici - zwłaszcza w XVII i XVIII wieku mieli znaczący wkład w rozwój duchowości maryjnej, patrystycznej i ascetycznej. Wybitni ludzie pióra z kręgu karmelitańskiego pozostawili po sobie dzieła, które do dnia dzisiejszego inspirują rozwój życia duchowego i teologię mistyczną.

W zespole starych druków biblioteki klasztoru karmelitów bosych w Czernej do chwili obecnej zachowało wiele dzieł podejmujących szeroko rozumiane zagadnienia z dziedziny teologii mistycznej, duchowości, prawodawstwa i kaznodziejstwa karmelitańskiego.

Mistycyzm hiszpański obecny w dziełach i nauce św. Teresy od Jezusa, św. Jana od Krzyża oraz takich pisarzy karmelitańskich jak o. Tomasz od Jezusa (1587-1627) i Jan od Jezusa Maryi (1564-1615), znalazł po 1605 roku gorących

* Ks. Waldemar Graczyk - prof. dr hab. historii, Instytut Nauk Historycznych UKSW, e-mail: waldemar-graczyk@wp.pl

${ }^{1}$ Niniejsze opracowanie jest częścią obszernej monografii W. Graczyka, Księgozbiór klasztoru-eremu karmelitów bosych w Czernej od XVII do końca XIX wieku. Studium z dziejów kultury intelektualnej i duchowej, Kraków 2011.

${ }^{2}$ O. Filek, Nauka i nauczanie w zakonach karmelitańskich, w: Dzieje teologii katolickiej, t. 2, cz. 2, red. M. Rechowicz, Lublin 1975, s. 377.

${ }^{3}$ Tamże. 
propagatorów na ziemiach polskich ${ }^{4}$. Karmelitańskie piśmiennictwo skupiało się zasadniczo w czterech grupach tematycznych: teologii życia wewnętrznego, teologii kontrowersyjnej, mariologii i szeroko pojętego kaznodziejstwa. Troska o poziom tego ostatniego była wyraźnie widoczna w działalności duszpasterskiej karmelitów bosych od początku ich obecności w Polsce. Przejawem aktywności teologicznej i kaznodziejskiej karmelitów są zachowane w bibliotece czerneńskiej liczne traktaty, rozprawy, przekłady pism mistyków hiszpańskich oraz kazania. W cennych zbiorach starych ksiąg, najliczniej reprezentowana jest twórczość z zakresu teologii życia wewnętrznego, niezmiernie ważnej w formowaniu całej duchowości karmelitańskiej. Klasztorna biblioteka przechowuje pisma pisarzy karmelitańskich z innych państw europejskich oraz przekłady ich dzieł na język polski. W księgozbiorze znajdują się dzieła św. Teresy Wielkiej, przełożone przez niestrudzonego propagatora jej pism - Sebastiana Nucerina, są to: Droga doskonatości przez święta Teresę napisana ..., wydana w Krakowie w drukarni Macieja Andrzejowczyka (Jędrzejowczyka) w 1623 roku $^{5}$, Księgi duchowne św. Matki Teresy od Pana Jezusa ..., z włoskiego na polski przez ojców tegoż zakonu przetożone i na dwa tomy rozdzielone, (Kraków 1664) ${ }^{6}$ oraz Zamek wewnętrzny albo gmachy duszy ludzkiej świętej Teresy od Pana Jezusa ..., przettumaczone z włoskiego na polski ...., wydane w oficynie Franciszka Cezarego w Krakowie w 1633 roku? Warto zaznaczyć, że Sebastian Nucerin (1565-1635) był niestrudzonym propagatorem na ziemiach polskich kultu i pism hiszpańskiej mistyczki, reformatorki zakonu karmelitów i karmelitanek, znakomitym i zasłużonym tłumaczem jej dzieł. Oprócz działalności translatorskiej i pisarskiej był też prawdziwym mistrzem kaznodziejstwa $^{8}$. Pełnił w latach 1611-1635 obowiązki kaznodziei w katedrze wawelskiej. Dał się wówczas poznać jako prawdziwie porywający mówca, trafiający do serc i rozumu słuchaczy. Nuceryn był mocno związany z karmelitami bosymi. Przyczynił też się do sprowadzenia karmelitanek bosych do Polski, zaś w 1630 roku wygłosił kazanie podczas uroczystej instalacji karmelitów bosych w Wiśniczu. Tuż przed śmiercią przekazał swój, zgromadzony w ciągu całego życia księgozbiór, karmelitom bosym z klasztoru pw. św. Michała i św. Józefa w Krakowie9. Przykładem jest wpis proweniencyjny: Conventus Cracoviensis SS. Michaelis et Josephi PP. Carmelitarum Discalceatorum ex donatione R. Dno Sebastiani Nu-

${ }^{4}$ Cz. Gil, Karmelici bosi w Polsce 1605-1655, Kraków 1977, s. 1-26; tenże, Czterysta lat karmelitów bosych w Polsce (1605-2005), w: Karmelici bosi w Polsce 1605-2005, red. Cz. Gil, Kraków 2005, s. 13-19.

${ }^{5}$ BKC, sygn. 475, poz. inw. 515.

${ }^{6}$ BKC, sygn. 258, poz. inw. 275.

${ }^{7}$ BKC, sygn. 259, poz. inw. 276.

${ }^{8}$ E. Ozorowski, Nucerin Sebastian (1565-1635), w: Stownik Polskich Teologów Katolickich (dalej: SPTK), t. 3, Warszawa 1982, s. 235-236; J.M. Marszalska, Nucerin Sebastian (1565-1635), w: Encyklopedia Katolicka (dalej: EK), t. 14, Lublin 2010, kol. 108; K. Panuś, Wkład karmelitów bosych w kaznodziejstwo polskie, w: Cztery wieki karmelitów bosych w Polsce (1605-2005), red. A. Ruszała, Kraków 2005, s. 246-248.

${ }^{9}$ H. Barycz, Nucerinus Sebastian (1565-1635), w: Polski Stownik Biograficzny (dalej: PSB), t. 23, Wrocław-Warszawa-Kraków-Gdańsk 1978, s. 406. 
cerini STD Custodis Ecclesiae Cathedralis Concionatoris. Anno Dni 1635, mense 20 septembra. Oretur pro eo, zamieszczony przez testatora na dziele Servatusa de Lairuleza Optica regulariam seu commentarii ... (Kolonia 1614) ${ }^{10}$.

Klasztory karmelitańskie, podobnie jak klasztory innych zakonów, gromadziły pisma teologiczne swoich rodzimych autorów. Jest to widoczne przy analizie zawartości niemal każdego zakonnego księgozbioru. Wiek XVII w historii Karmelu bosego w Polsce zapisał się pierwszym aktywnym twórczo pokoleniem zakonników, których spuścizna intelektualna, duchowa i kaznodziejska jest niepodważalna. Badacze duchowości i historii karmelitów bosych w Polsce ${ }^{11}$ zgodnie uważają, że najwybitniejszymi autorami rozlicznych dzieł teologiczno-mistycznych wywodzących się z szeregów zakonu byli wówczas: Mikołaj od Jezusa i Maryi (Opacki, 1594?-1627), Sebastian od Wszystkich Świętych (Bolski, 16101684), Hieronim od św. Jacka (Cyrus, 1603-1647), Stefan od św. Teresy (Kucharski, 1595-1653), Bonawentura od św. Stanisława (Frezer, 1638-1687), Andrzej od Jezusa (Brzechwa, 1584-1640) oraz Ignacy od św. Jana Ewangelisty (zm. 1677) - autor biografii matki Teresy Marchockiej, opartej na jej Autobiografii mistycznej. Spośród teologów hiszpańskich na język polski thumaczone były i szybko wydawane w krakowskich oficynach wydawniczych dzieła Jana od Jezusa i Maryi (Juan de San Pedro y Ustawoz, 1564-1615) i Tomasza od Jezusa (Sanchez Davila, 1564-1627). Dzieła wymienionych autorów obecne są również w księgozbiorze czerneńskim.

Oprócz pism ascetyczno-mistycznych oraz pism z zakresu kaznodziejstwa, podejmowano pierwsze próby opracowywania zagadnień dotyczących duchowości w formie monografii lub podręcznika ${ }^{12}$. Traktaty z zakresu duchowości autorstwa Hieronima od św. Jacka (Cyrus) poruszały współcześnie ważne zagadnienia jakim są: wolność człowieka, jego kultura wewnętrzna oraz godność osoby i jej dobre imię ${ }^{13}$. W klasztornej bibliotece czerneńskiej zachowało się kilka ważnych podręczników z teologii życia duchowego, napisanych przez autorów hiszpańskich lub włoskich. Rekolekcje tematyczne (często wcześniej głoszone) a opracowane w formie pism przez XVII-wiecznych karmelitańskich profesorów teologii, miały zawsze jakąś ideę centralną: stopnie pokory, posłuszeństwo, przygotowanie się na cierpienie, ostateczny rozrachunek z życia ${ }^{14}$.

Wspomniany wcześniej karmelita hiszpański Jan od Jezusa i Maryi (Juan de San Pedro y Ustawoz) jest autorem Instructio novitiorum et disciplina claustralis ... (Leodii 1671) ${ }^{15}$, wydanej po raz pierwszy w Rzymie w 1605 roku a potem wielokrotnie wznawianej. Dzieło to w thumaczeniu karmelity bosego, Cyryla od św. Franciszka ukazało się w oficynie bazylianów w Wilnie w 1641 roku, pt. Instruk-

${ }^{10}$ BKC, sygn. 1015, poz. inw. 1079.

${ }^{11}$ K. Górski, Teologia ascetyczno-mistyczna (wiek XVI-XVIII), w: Dzieje teologii katolickiej, t. 2, cz. 1, red. M. Rechowicz, Lublin 1975, s. 458-460; Gil, Czterysta lat karmelitów bosych $w$ Polsce (1605-2005), s. 23-24.

${ }^{12}$ Filek, Nauka i nauczanie w zakonach karmelitańskich, s. 381.

${ }^{13}$ Tamże.

${ }^{14}$ Tamże.

${ }^{15}$ BKC, sygn. 631, poz. inw. 677. 
cyja dla Nowicjuszów od Wielebnego Oyca Jana a Jesu Maria Karmelity Bosego napisana ... Dedykowane było Annie Sobieskiej, ksieni zakonu brygidek w Grodnie ${ }^{16}$. Kilka innych dzieł tego autora - Liber de bono usu curiae compendio scriptus per R.P.F. Ioannem a Iesu Maria carmelitam discalceatum Calaguritanum ..., (Kraków 1614) ${ }^{17}$; Disciplina claustralis sive practica actum vitae religiose ut cum spiritu et perfecte exerceantur carmelitis discalceatis ..., (Kraków 1676) ${ }^{18}$; Schola orationis contemplationis et mortificationis Passionum ..., wydane w poznańskiej oficynie Jana Wolraba w 1623 roku $^{19}$ oraz w przekładzie polskim Ferdynanda od św. Maryi: Ćwiczenia klasztorne albo praktyka uczynków albo aktów żywota zakonnego żeby duchownie i doskonale odprawione byty ..., (Kraków 1645) ${ }^{20}$ - przechowała biblioteka czerneńska aż do czasów nam współczesnych. Świadczy to o wielkiej popularności pism Jana od Jezusa i Maryi w polskim środowisku karmelitańskim. Warto zaznaczyć, że był on obok wielkich reformatorów Karmelu najbardziej wybijającą się postacią reformy terezjańskiej na przełomie XVII i XVIII wieku, a także wytrawnym znawcą teologii scholastycznej i myśli św. Teresy od Jezusa. Przejawem jego uznania był fakt, iż został włączony do zaszczytnego grona doradców teologicznych papieża Klemensa VIII i konsultora kongregacji De auxiliis Divinae Gratiae. Jan od Jezusa i Maryi był też spowiednikiem znakomitego teologa (późniejszego świętego) Roberta Bellarmina i przyjacielem św. Józefa Kalasantego. Jego liczne dzieła wydawano w wielu krajach europejskich w tym również i w Polsce ${ }^{21}$.

W księgozbiorze czerneńskim odnotowanych jest kilka dzieł innego, wybitnego karmelity hiszpańskiego Tomasza od Jezusa (Sanchez Davila, 1564-1627), którego traktaty mistyczne zostały przetłumaczone na język polski. Na półkach biblioteki zachowały się jego Orationis mentalis via brevis et plana ..., wydane w krakowskiej oficynie Franciszka Cezarego w 1626 roku ${ }^{22}$ oraz Krótki sposób rozbierania i rozeznania postepku duchownego przez Wielebnego w Chrystusie Tomasza a Iesu ... (Kraków 1645) ${ }^{23}$. Do tego dzieła doklejone zostały napisane odręcznie Ćwiczenia klasztorne albo praktyka uczynków.

Jak to zostało już zasygnalizowane, zakon w znacznej mierze bazował na traktatach i podręcznikach autorów hiszpańskich i włoskich, chociaż karmelici polscy mieli już własne opracowanie systematyzujące naukę teologiczną. Dokonał tego Sebastian od Wszystkich Świętych (Bolski) w dziele pt. Exemplar vitae spiritualis et perfectionis seu exercictia huius vitae practica pro tronibus carmelitis discalceatis ..., wydanym po raz pierwszy w 1678 roku w oficynie Marcina Sche-

\footnotetext{
${ }^{16}$ Bibliografia Polska, t. 18, oprac. K. Estreicher, Kraków 1901, s. 410.

${ }^{17}$ BKC, sygn. 471, poz. inw. 510.

${ }^{18}$ BKC, sygn. 472, poz. inw. 517.

${ }^{19}$ BKC, sygn. 891, poz. inw. 953.

${ }^{20}$ BKC, sygn. 688, poz. inw. 637.

${ }^{21}$ Cz. Gil, Mistrz Jan od Jezusa i Maryi (1564-1614). Życiorys, modlitwy i medytacje, Kraków

${ }^{22}$ BKC, sygn. 472, poz. inw. 512; Bibliografia Polska Karola Estreichera, wyd. S. Stanisław Estreicher, t. 31, Kraków 1936, s. 201.

${ }^{23}$ BKC, sygn. 218, poz. inw. 234.
} 1998, s. 5-6. 
dla w Krakowie ${ }^{24}$. Dwa egzemplarze pierwszego wydania dzieła i dwa drugiego, z dopiskiem nunc vero sumptibus Provinciae Lithuaniae reimpresa, wydane w Wilnie w 1741 roku przez oficynę Academicis Societas Iesu, odnotowuje biblioteka czerneńska ${ }^{25}$. Według znawców przedmiotu, w podręczniku tym Sebastian od Wszystkich Świętych (Bolski) pozostał wierny pierwotnej metodzie wychowawczej, ustalonej przez mistrzów karmelitańskich takich jak Jan od Jezusa i Maryi. W swoim traktacie zwracał uwagę na formację życia emocjonalnego, podkreślając, że ta bardzo ważna sfera życia ludzkiego, pozostawiona samej sobie, może stać się źródłem wad i wielu niepotrzebnych komplikacji, poddana rozumowi i roztropności, może być podstawą rozwoju wielu cnót. Karmelici czerneńscy korzystali w ciągu wieków z tego swoistego podręcznika „pedagogiki”. Do chwili obecnej zachowało się na półkach klasztornej biblioteki kilka egzemplarzy tego dzieła, co dowodzi niezbicie, że był on wykorzystywany w formacji zakonnej ${ }^{26}$.

W kręgu wspomnianej teologii życia wewnętrznego pozostają dzieła Mikołaja od Jezusa i Maryi (Opacki, 1594-1627), polskiego teologa i mistyka karmelitańskiego, wykładowcy teologii w studium karmelitańskim w Lublinie i Krakowie ${ }^{27}$. Zagadnienie kontemplacji i życia wewnętrznego było dla niego przedmiotem naukowej refleksji. W dziele Apologia perfectionis vitae spiritualis sive propugnaculum religiorum omnium ..., wydanym w 1628 roku w Rzymie w oficynie Corbelletiego ${ }^{28}$, stawiał a zarazem naukowo uzasadniał tezę, że życie kontemplacyjno-czynne jest doskonalsze od życia wyłącznie czynnego lub życia wyłącznie kontemplacyjnego ${ }^{29}$. Przyczynił się tym samym do sprostowania wielu zniekształconych pojęć o życiu duchowym, działalności apostolskiej oraz praktykowaniu rad ewangelicznych i ascezy ${ }^{30}$. Dzieło to dedykowane Stanisławowi Lubomirskimu, kasztelanowi wiśnickiemu, podczaszemu koronnemu, przyniosło autorowi międzynarodowy rozgłos i zainteresowanie w całej niemal Europie. Apologię Opackiego wydały oficyny w Rzymie $(1626,1628)$, Krakowie (1627), Duaci (1629, 1630), Ratyzbonie (1631) i Genui (1653). Jedyny zachowany egzemplarz w bibliotece czerneńskiej nosi zapis własnościowy klasztoru-eremu: Conventus eremi S.P.N. Eliae Czernensis, wraz z odręcznym zapisem: Ta ksiązka należy do rzadkości. Jest to widocznym potwierdzeniem unikatowości pism Opackiego.

Współczesny Mikołajowi od Jezusa i Maryi był inny wybitny mistyk karmelitański, dzisiaj właściwie zapomniany - Stefan od św. Teresy (Kucharski, 15961653), autor 27 traktatów moralnych i ascetycznych, z których żaden nie ukazał się drukiem. Ocalało kilka jego bezcennych rękopisów. Opis życia Stefana od św.

${ }^{24}$ BKC, sygn. 101, poz. inw. 111; BKC, sygn. 223, poz. inw. 239.

${ }^{25}$ BKC, sygn. 630, poz. inw. 675; E. XIII, s. 245; BKC, sygn. 634, poz. inw. 680.

${ }^{26}$ Filek, Nauka i nauczanie w zakonach karmelitańskich, s. 382.

${ }^{27}$ Górski, Teologia ascetyczno-mistyczna (wiek XVI-XVIII), s. 458.

${ }^{28}$ BKC, sygn. 210, poz. inw. 226; Bibliografia Polska Karola Estreichera, wyd. S. Stanisław Estreicher, t. 23, Kraków 1910, s. 354-356.

${ }^{29}$ Filek, Nauka i nauczanie w zakonach karmelitańskich, s. 380.

${ }^{30}$ Tamże; Górski, Teologia ascetyczno-mistyczna (wiek XVI-XVIII), s. 458. 
Teresy został zamieszczony w dziele Filipa od św. Trójcy ${ }^{31}$ pt. Ozdoba Karmelu zakonnego w splendorach świętych $i$ życia doskonatościa znaczniejszych karmelitów $i$ karmelitanek ... (Kraków 1747) ${ }^{32}$, do którego dołączono Konferfekt z życia przykładnego z ozdoby Karmelu zakonnego kopiowany ..., gdzie podano 66 biogramów polskich karmelitów, których autorem był Onufry Osmólski ${ }^{33}$. W 2011 roku Karmelitański Instytut Duchowości, działający od 1991 roku w Krakowie, wydał trzy traktaty Stefana od św. Teresy: Baranek Wielkanocny, Traktat o modlitwie i O gruncie pokory zwanym nic ${ }^{34}$. Stefan od św. Teresy pisał traktaty mistyczne głównie na podstawie własnych doświadczeń religijnych. Był zwolennikiem umiarkowanej ascezy, której podwaliną jest posłuszeństwo i rozum ${ }^{35}$.

W pierwszym pokoleniu karmelitów polskich odnotowujemy obecność kilku wybitnych postaci, które znacząco wpłynęły na rozwój duchowy i intelektualny tego zakonu na ziemiach ówczesnej Rzeczypospolitej. Należał do nich Hieronim od św. Jacka (Cyrus, 1603-1647), uczestnik Colloquium Charitativum w Toruniu w 1645 roku, który pozostawił po sobie dzieło Idea Colloqui Charitativi cum dissidentibus Thorunii Anno Domini 1645 in dicti, accesit animadversio in Ioannem Culsemanum, ministrum Witembergensem ... (Kraków 1646). Warto podkreślić, że Colloquium Charitativum, czyli spotkanie katolików, luteran i kalwinistów, zwołane w 1645 roku przez króla Władysława IV Wazę do Torunia miało na celu przywrócenie jedności i zgody między wyznaniami chrześcijańskimi. Choć spotkanie nie przyniosło spodziewanych rezultatów, to jednakże wzbudziło pełny szacunek dla duchowych i politycznych przywódców Rzeczypospolitej. Spotkanie to powszechnie uznaje się za początek ekumenizmu na ziemiach polskich ${ }^{36}$. Spośród 17 traktatów, które pozostawił po sobie Hieronim od św. Jacka, dziewięć zostało ogłoszonych drukiem. Biblioteka czerneńska przechowuje jego Manipulus fasciculorum spiritualium selectissimorum et plane aureorum ex Divino agro sacre scripturae ..., wydane w Monachium w 1708 roku $^{37}$.

W teologii systematycznej karmelici bosi w XVII i XVIII wieku wiernie trzymali się nurtu tomistycznego. Było to szczególnie widoczne w pisarstwie teologicznym Roberta od Świętego Ducha (Koncewicz), a zwłaszcza w jego dziele pt. De laudibus D. Thomae de Aquino Angelici ecclesiae doctoris oratio Roberti a Spiritu S. Carmelitae Discakceati ... (Wilno 1770) ${ }^{38}$.

${ }^{31}$ Nie udało się zidentyfikować jego nazwiska. Zmarł w 1697 roku w Przemyślu, gdzie został pochowany w podziemiach kościoła pw. św. Teresy. Por. B.J. Wanat, Zakon Karmelitów Bosych w Polsce. Klasztory karmelitów i karmelitanek bosych 1605-1975, Kraków 1979, s. 276.

${ }^{32}$ BKC, sygn. 150, poz. inw. 164.

${ }^{33}$ Tamże.

${ }^{34}$ S. Kucharski, Dzieła, t. 1, oprac. M.A. Sopart, Kraków 2011, s. 21-23.

${ }^{35}$ Filek, Nauka i nauczanie w zakonach karmelitańskich, s. 378-379.

${ }^{36}$ E. Piszcz, Colloquium Charitativum, EK, t. 3, Lublin 1979, kol. 546-547.

${ }^{37}$ BKC, sygn. 755, poz. inw. 806. E. XIV, s. 501. Dzieło to jako jedyne zostało podane przez K. Estreichera z przyporządkowaniem bibliotece eremu czerneńskiego.

${ }^{38} \mathrm{BKC}$, sygn. 266 adl. 21, poz. inw. 303. W 1778 r. przebywał jako zakonnik konwentualny w klasztorze-rezydencji w Gudohajach na Litwie. Por. B.J. Wanat, Zakon Karmelitów Bosych w Polsce, s. 571-572. 
Zagadnienia teologiczne były poruszane w dziełach, które mimo różnorodnej proweniencji klasztornej w obrębie prowincji karmelitów bosych są przechowywane w bibliotece czerneńskiej. Są to: Placyda od św. Teresy, Orationes theologicae varris in logis habitae ... (Bruxellis 1648) ${ }^{39}$, Collegi Salamancensis Fr. Discalceatorum B. Mariae de Monte Carmeli cursus theologicus ... (Wenecja $1677)^{40}$ oraz Izydora od św. Andrzeja Historia generalis Fratrum Discalceatorum Ordinis Virginis Mariae de Monte Carmelo Congregationis S. Eliae ... (Rzym $1668)^{41}$.

Na szczególną uwagę zasługują dzieła dawnych autorów karmelitańskich, w których z teologią życia duchowego organicznie łączy się duchowość maryjna. Jest to $\mathrm{w}$ pełni zrozumiałe, ponieważ kult maryjny stanowił istotną i znaczącą cechę zakonu karmelitańskiego ${ }^{42}$. Z kultem maryjnym wiązało się też istnienie bractw szkaplerznych, chociaż początkowo ustawodawstwo zakonne niezbyt chętnie godziło się na ich erygowanie przy klasztorach ${ }^{43}$. Dla potrzeb członków bractwa szkaplerznego wydawano popularne modlitewniki, np. Cypriana od św. Maryi Thesaurus Carmelitarum sive de confraternitate sacri scapularis Beati Virginis Mariae do Monte Carmelo ... (Kolonia 1627), odnotowany w księgozbiorze czerneńskim ${ }^{44}$. Na język polski przetłumaczył go Przemysław Domiechowski, cysters, ówczesny przeor klasztoru w Mogile, późniejszy opat szczyrzycki. W zbiorze ksiąg klasztoru-eremu obecny jest wspomniany modlitewnik w thumaczeniu polskim: Skarb karmelitański, to jest traktat, gdzie po krótkiej historyjej o poczatku i postępku starodawnego zakonu karmelitańskiego daję się nauka o Bractwie Szkaplerza Świętego, Błogosławionej Pannie Maryjej z Góry Karmelu ..., wydany w 1653 roku, w Krakowie, w drukarni Franciszka Cezarego ${ }^{45}$. Modlitewnik w przeszłości należał do Panien karmelitanek bosych w Wilnie, co poświadcza zapis proweniencyjny na karcie tytułowej. W przedmowie wydania odnotowano nazwisko tłumacza: ,[...] przy tym kładzie się krótkie zebranie przywilejów, łask i odpustów bractwa z powinnościami ich przez W. X. Przemysława Domiechowskiego, przeora mogilskiego przetłumaczone z przydatkiem wielu nauk potrzebnych $[\ldots]]^{\prime 46}$.

${ }^{39}$ BKC, sygn. 599, poz. inw. 644.

${ }^{40}$ BKC, sygn. 410 , poz. inw. 442.

${ }^{41}$ BKC, sygn. 74, poz. inw. 82.

${ }^{42}$ Filek, Nauka i nauczanie w zakonach karmelitańskich, s. 382-383.

${ }^{43}$ Początki bractwa szkaplerznego sięgają XIII wieku. Od czasu objawienia się Matki Bożej św. Szymonowi Stockowi (1251) i nadania wielkich przywilejów karmelitańskiemu szkaplerzowi rozpoczął się masowy kult Najświętszej Maryi Panny Szkaplerznej. W krótkim czasie erygowano bractwa szkaplerzne przy wszystkich klasztorach karmelitańskich. Stanowiły one jedną z ważniejszych form działalności zakonu. Prawo erygowania bractw szkaplerznych zastrzeżone było dla przełożonych generalnych zakonu karmelitańskiego. Por. B.J. Wanat, Zakon Karmelitów Bosych w Polsce, s. 723-724; Gil, Czterysta lat karmelitów bosych w Polsce (1605-2005), s. 25.

${ }^{44}$ BKC, sygn. 1251, poz. inw. 1331.

${ }^{45}$ BKC, sygn. 1440, poz. inw. 1520.

${ }^{46}$ Przemysław Domiechowski, h. Prawdzic (1602-1684), z pochodzenia wielkopolanin; w 1625 roku wstąpił do klasztoru cystersów w Mogile, gdzie 12 marca 1626 roku złożył profesję zakonną. Święcenia kapłańskie otrzymał w 1633 roku; około 1645 roku został mianowany przez opata mo- 
W bibliotece znajdują się również ważne dzieła odnoszące się do historii Karmelu: Ozdoba Karmelu zakonnego w splendorach świętych $i$ życia doskonatościa znaczniejszych karmelitów i karmelitanek któremi zakon Najświętszej Maryi Panny z góry Karmelu od Eliasza ufundowany ... (Lublin 1746) ${ }^{47}$. Część pierwsza tegoż dzieła została dedykowana księżnej Konstancji Kolumbie z Denhoffów Sanguszkowej, żonie Janusza Aleksandra Sanguszki, miecznika Wielkiego Księstwa Litewskiego, znanej z hojności wobec karmelitów i benedyktynów ${ }^{48}$. W części drugiej, wydanej w tym samym roku w Krakowie, zamieszczony został regestr żywotów polskich karmelitów i karmelitanek bosych z przełomu XVII i XVIII wieku. Następne to wspomniany Konferfekt życia przyktadnego z Ozdoby Karmelu zakonnego kopiowany, kolorami chwalebnymi cnót świąobliwości karmelitów $i$ karmelitanek bosych ... (Kraków 1747) ${ }^{49}$ oraz Chwała i godność zakonu karmelitańskiego w Najświętszej Maryi Pannie, Matce, Patronce i Ozdobie swej także $w$ świętych karmelitach jaśniejaca, czyli nowenna ... z septenna do S.O. i Patriarchy Eliasza przez niedziel siedem podana, wydane również w Krakowie w $1768^{50}$. Są one ważnym źródłem do badań nad prosopografią zakonną w Polsce.

Bez wątpienia dziedziną, w której karmelici bosi wyraźnie zaznaczyli swoją widoczną aktywność w dawnej religijności było kaznodziejstwo. Kazania głoszone w różnych kościołach (nie tylko karmelitańskich) z reguły wydawane były drukiem. Pierwszym, uznanym kaznodzieją wywodzącym się z grona karmelitów był Hieronim od św. Jacka (Cyrus) ${ }^{51}$. W 1636 roku, po śmierci Sebastiana Nucerina, został mianowany przez biskupa krakowskiego Jakuba Zadzika kaznodzieją katedralnym krakowskim. Jak powszechnie wiadomo Sebastian Nucerin w środowisku stołecznym królewskiego Krakowa uchodził za niedościgniony wzorzec kaznodziei i oratora ${ }^{52}$. W Żywocie Wielebnego Ojca Hieronima, zamieszczonym w dziele Ozdoba Karmelu zakonnego w splendorach świętych..., inny karmelita, Filip od Trójcy Przenajświętszej, zanotował, że Hieronim od św. Jacka w pełni wywiązał się z przyjętego na siebie obowiązku ${ }^{53}$. W syntezie dziejów kaznodziejstwa napisanej pod koniec XIX stulecia pt. Zarys dziejów kaznodziejstwa w Kościele katolickim J.S. Pelczar, stwierdził, że „Hieronim od św. Jacka zajaśniał na ambonie jako żarliwy kaznodzieja" ${ }^{54}$.

gilskiego Pawła Piaseckiego przeorem klasztoru; 25 czerwca 1658 roku został opatem klasztoru cystersów w szczyrzycu z prezenty króla Jana Kazimierza Wazy. Por. J.M. Marszalska, W. Graczyk, Opaci i przeorzy klasztoru oo. cystersów w Szczyrzycu od XIII do XX wieku, Kraków-Tyniec 2006, s. 130.

${ }^{47}$ BKC, sygn. 149, poz. inw. 163.

${ }^{48}$ M. Czeppe, R. Marcinek, Sanguszkowa z Denhoffów 2v Rogalińska Konstancja Kolumba (1716-1791), PSB, t. 34, Wrocław-Warszawa-Kraków 1992, s. 523-524.

${ }^{49}$ BKC, sygn. 150, poz. inw. 164.

${ }^{50} \mathrm{BKC}$, sygn. 828, poz. inw. 884.

${ }^{51}$ Panuś, Wktad karmelitów bosych w kaznodziejstwo polskie, s. 246-247.

${ }^{52}$ K. Panuś, Kaznodziejstwo w katedrze krakowskiej, cz. 1. Od poczatków do czasów rozbiorów, Kraków 1995, s. 16; E. Ozorowski, Nucerin Sebastian (1565-1635), SPTK, t. 3, s. 235-236; J.M. Marszalska, Nucerin Sebastian (1565-1635), EK, t. 14, Lublin 2010, kol. 108.

${ }^{53}$ BKC, sygn. 149, poz. inw. 163.

${ }^{54}$ J.S. Pelczar, Zarys dziejów kaznodziejstwa w Kościele katolickim, cz. 2, Kraków 1896, s. 182. 
W zbiorze czerneńskim zachowały się dwa jego dzieła o tematyce teologiczno-polemicznej: wspomniane już Idea Colloquii Charitativi cum dissidentibus Thorunii Anno Domini 1645 in dicti, accesit animadversio in Ioannem Culsemanum, ministrum Witembergensem ... (Kraków 1646) oraz osobno wydane Animadversio in Ioannem Hulsemanum ministrum Witembergensem ... (Kraków 1646). Hieronim od św. Jacka znany był głównie jako kaznodzieja pogrzebowy, a pompa funebris kreślona ręką karmelitów bosych w XVII stuleciu stanowi znakomity przyczynek do dziejów polskiej kultury ostatniego pożegnania ze zmarłymi. W bibliotece klasztornej zachowało się jego Kazanie na pogrzebie Jej Mci Panny Martiany Daniłlowiczównej Koniecpolskiej w kościele przecławskim miane ..., wydane w 1646 roku, w Krakowie, w oficynie Andrzeja Piotrkowczyka ${ }^{55}$.

Kaznodziejstwo karmelitańskie w dużej mierze przetrwało w rękopisach ${ }^{56}$. Tylko kilku karmelitów bosych - oprócz Hieronima od św. Jacka (Cyrus) - doczekało się wydania drukiem swoich kazań. Z kręgu karmelitańskiego w księgozbiorze czerneńskim odnotowujemy między innymi kazania karmelity Anioła od Ofiarowania Najświętszej Maryi Panny: Kazania o życiu miękkim i rozkosznym $w$ piatki marcowe kolegiacie warszawskiej miane, wydane $\mathrm{w}$ drukarni Fortecy Najświetszej Maryi Panny w Berdyczowie w 1785 roku $^{57}$ oraz Kazania na uroczystości Maryi w różnych kościołach miane ..., (Berdyczów 1786) ${ }^{58}$. Spośród kazań niedzielnych o tematyce polemicznej zachowało się kazanie Maksymiliana od Najświętszej Maryi Panny (Karpowicz) pt. Kazania niedzielne dogmatyczno -moralne ... przeciwko kacerzom naprzeciw wierze nauczajacym i prawowiernym nie wedtug wiary czyniacym ... (Wilno 1773) ${ }^{59}$. Jego kazania i mowy głoszone na różne okazje (najczęściej w kościołach karmelitańskich) cieszyły się u współczesnych dużym uznaniem (np. kazanie wygłoszone w 1764 roku w odnowionej tuż po pożarze kaplicy Matki Bożej Ostrobramskiej w Wilnie) ${ }^{60}$. Inny karmelita, Anioł od Ducha Swiętego (Kaczorowski) pełniący funkcję prowincjała w latach 1799-1800 ${ }^{61}$, był autorem Kazania między oktawa uroczystej koronacji Niepokalanie Poczętej Najświętszej Maryi Panny cudami stynacej ... (Lwów 1778) ${ }^{62}$, wygłoszonego w 1778 roku w kościele ojców Franciszkanów w Przemyślu. Jest to jedyne jego kazanie, które się zachowało się do naszych czasów.

Druga połowa XVII wieku wniosła do polskiego kaznodziejstwa silny element panegiryczny. Kaznodzieje i pisarze zakonni głosili chwałę „mężnych szlachciców, potężnych magnatów czy bogatych i znaczących mieszczan”. Sposobność do pisania panegiryków dawały różne okazje, np. narodziny, zaślubiny

${ }^{55}$ BKC, sygn. 756, poz. inw. 808.

${ }^{56}$ W Archiwum klasztoru czerneńskiego zachowało się dość dużo mów i kazań pochodzących z XVIII bądź z początku XIX stulecia.

${ }^{57}$ Biblioteka przechowuje dwa identyczne egzemplarze tego dzieła. BKC, sygn. 526, poz. inw. 568; BKC, sygn. 451, poz. inw. 485.

${ }^{58}$ BKC, sygn. 527, poz. inw. 567.

${ }^{59} \mathrm{BKC}$, sygn. 530, poz. inw. 572.

${ }^{60}$ Wanat, Zakon Karmelitów Bosych w Polsce, s. 292.

61 Tamże, s. 82.

${ }^{62}$ BKC, sygn. 266 adl 22, poz. inw. 304. 
czy zgony. Wszelkie panegiryki, pisane zarówno na uroczystości radosne, jak i żałobne, zawierały zazwyczaj sporo przesadnego zachwytu i pochlebstwa. Kazania panegiryczne powstawały według określonego schematu, według ustalonego wzoru również były wygłaszane. Pełne patosu, miały służyć ukazaniu jedynej drogi wiodącej ku zbawieniu, poprzez pamięć ujętą w zapisanych słowach o czynach, dobroci i hojności zmarłych. Droga jaką wskazywali również karmelitańscy kaznodzieje, było pobożne życie chrześcijańskie, poświęcone na służbę i chwałę Bogu. Jednoznacznie negatywny obraz śmierci nie przeszkadzał kaznodziei konstruować całkiem doczesnej, panegirycznej pochwały zmarłych magnatów, szlachciców i szlachcianek - ludzi dobrze urodzonych ${ }^{63}$.

Karmelici bosi wielokrotnie głosili, a potem wydawali drukiem kazania z okazji pogrzebów znaczniejszych osób. Wizerunki śmierci ukazywane w mowach pogrzebowych, których byli autorami, często oscylowały między określeniem śmierci jako przebiegłego wroga, a Chrystusem, wybawicielem człowieka z marnej powłoki cielesności ${ }^{64}$. Tak skonstruowane jest zachowane w bibliotece czerneńskiej kazanie funebralne Cyryla od Poślubienia Najświętszej Maryi Panny, lektora teologii w Kolegium wileńskim, Konjectura z aspektu herbownej Jaśnie Wielmożnych Ich Mciów PP. Strutyńskich i Ojczystej reformowanego Karmelu konstelacyi upatrzona dla Jaśnie Wielmożnego Imci Pana Jana na Strutynie Strutyńskiego, kasztelana inflanckiego, przy remissyi doczesnego życia i rezolucyi śmiertelnego ciata ..., wydane w Wilnie w drukarni akademickiej w 1746 roku $^{65}$, a także kazanie Aleksandra od Niepokalanego Poczęcia Najświętszej Maryi Panny, wygłoszone w kościele karmelitów bosych pw. św. Michała i św. Józefa w Krakowie, a poświęcone osobie Władysława z Lubrawia Dąbskiego pt. Castris et astris Marsowi i Jezusowi hołdujacy kawaler JP Władystaw z Lubrawia Dabski, towarzysz Jerzego Bogusława Stuszki ..., marszałka nadwornego Wielkiego Księstwa Litewskiego żegnany, (Kraków 1684) ${ }^{66}$.

Biografia a zwłaszcza kazania pogrzebowe rozsławiły innego karmelitę Aleksandra od Jezusa (Kochanowski, 1618-1667), pochodzącego ze „słynnej literackiej dynastii Kochanowskich" ${ }^{67}$. Był przełożonym klasztorów w Wiśniczu, Lwowie i Krakowie, a także wybitnym mówcą swoich czasów. Jego kazania cechuje czysty i podniosły język. Unikał makaronizmów ${ }^{68}$. Głosił kazania na pogrzebach najznaczniejszych magnatów epoki, w której żył, między innymi, marszałka wielkiego koronnego Stanisława Lubomirskiego, podskarbiego koronnego Jana Mikołaja Daniłowicza, marszałka i rokoszanina Jerzego Sebastiana Lubomirskie-

${ }^{63}$ J.M. Marszalska, Kaznodziejstwo barokowe jako element teatru pompa funebris. Kilka uwag $z$ dziejów obrazowania idei marności, w: Cnoty i wady. Społeczeństwo Baroku po obu stronach Karpat, red. J. Marecki, L. Rotter, Kraków 2007, s. 41-42.

${ }^{64}$ Tamże.

${ }^{65}$ BKC, sygn. 266, poz. inw. 287.

${ }^{66}$ BKC, sygn. 22 adl 3, poz. inw. 28.

${ }^{67}$ K. Panuś, Wkład karmelitów bosych w kaznodziejstwo polskie, s. 249; A. Nowicka-Struska, Klio - znaczy chwalić. Historia, czasy i ludzie w XVII wiecznych pogrzebowych kazaniach karmelitańskich, w: Karmelici bosi w Polsce 1605-2005, red. Cz. Gil, Kraków 2005, s. 49-50;

${ }^{68}$ J. Duchniewski, Kochanowski Andrzej (1618-1667), EK, t. 9, Lublin 2002, kol. 259-260. 
go, biskupa krakowskiego Piotra Gembickiego, hetmana wielkiego koronnego Stanisława Rewery-Potockiego, i wielu innych. W bibliotece klasztornej pisma Aleksandra od Jezusa (Kochanowskiego) należą do rzadkości. Zachowały się zaledwie dwa jego kazania funebralne i traktat teologiczno-filozoficzny Metaphisica iuxta genuinam D. Thomae Aquinatis ..., wydany w Krakowie w 1679 roku, niestety już po śmierci autora ${ }^{69}$. Aleksander od Jezusa pozostawił wspomniany traktat w zarysie, dokończył go już po śmierci autora jego uczeń - Ireneusz od Wniebowstąpienia Pańskiego (Orzeszko), bratanek Sebastiana Nucerina. Kazanie pogrzebowe, poświęcone osobie Stanisława Rewery na Potoku Potockiego zostało wygłoszone przez Aleksandra od Jezusa (Kochanowski) w Podhajcach dnia 20 czerwca 1667 roku, wydano je w Krakowie w oficynie Krzysztofa Schedla również w 1667 roku. Jest to jedno z ostatnich kazań funebralnych Kochanowskiego, w którym w pełni zajaśniała retoryka pompa fenebris: Jaśnie Wielmożny Stanistaw na Potoku Potocki, wojewoda krakowski, hetman wielki koronny, starosta z cnót, z męstwa, z dzielności w żywy obraz sławnego wojsk izraelskich regimentarza ..., przy ostniej ciału jego martwemu na ustudze ... (Kraków 1667) ${ }^{70}$. Na karcie tytułowej kazania zapisano odręcznie: „,in saeculo Andreas Kochanowski”. „Chowając słowem" w 1667 roku hetmana Potockiego, Aleksander od Jezusa ukazał go jako wodza, rycerza, który niemal całe życie spędził w siodle. Wspominał go jako uczestnika wojen kozackich, przemilczając jego wcześniejsze wyprawy. Nie wspomniał zupełnie o wojnie szwedzkiej. Można przypuszczać, że specjalnie ominął ten temat, gdyż Stanisław Potocki złożył przysięgę na wierność Karolowi Gustawowi. Choć w grudniu 1655 roku odstąpił od króla szwedzkiego, już nigdy nie odzyskał wiarygodności w oczach Jana Kazimierza Wazy ${ }^{71}$. Pochwała Potockiego w kazaniu wygłoszonym w Podhajcach wypływała głównie z jego udziału w wojnie kozackiej i z postawy synów, którzy zajęli zgoła odmienne stanowisko niż zmarły ojciec w kwestii wojny ze Szwecją. Laudacja dotyczyła nie tyle osoby zmarłego hetmana, gdyż zbyt wielu jego cnót kaznodzieja nie odnalazł, ile rodziny Pilawitów-Potockich, zarówno antenatów jak i młodych przedstawicieli rodu.

W każdym kazaniu pogrzebowym Kochanowskiego była zawarta pochwała rodu, jego dokonań, znaczenia w historii, znamienitych czynów i bogobojności. W kazaniu, które wygłosił w kościele podhajeckim nad trumną zmarłego hetmana, szala pochwał najwyraźniej przechyliła się na stronę rodu, delikatnie omijając nie zawsze najszczytniejszą postawę głównego bohatera pompa funebris.

Z końca XVIII wieku zachowało się zaledwie jedno kazanie, którego autorem był Henryk od Najświętszej Maryi Panny Anielskiej (Nowacki, 1747-1814) ${ }^{72}$. Dwukrotnie pełnił urząd prowincjała (1802-1805 oraz 1811-1814) a także spo-

${ }^{69}$ BKC, sygn. 269, poz. inw. 285 Aleksander od Jezusa (Kochanowski) występował w literaturze po imieniem: Aleksander a Iesu, Aleksander od Dzieciątka Jezus, Aleksander a Iesu Maria. Zob. A. Jocher, Obraz bibliograficzno-historyczny literatury $i$ nauk $w$ Polsce, od wprowadzenia do niej druku po rok 1830 wtacznie, t. 2, Wilno 1842, s. 70.

${ }^{70}$ BKC, sygn. 266 adl 1, poz. inw. 283.

${ }^{71}$ A. Przyboś, Potocki Stanisław, zwany Rewera (ok. 1589-1667), PSB, t. 28, Wrocław-Warszawa-Kraków-Gdańsk 1984-1985, s. 140-151.

72 J.M. Marszalska, Nowacki Henryk (ok. 1747-1814), EK, t. 14, Lublin 2010, kol. 27. 
wiednika i kaznodziei, który swoją zdecydowaną postawą wobec zaborców bronił zakonu przed kasatami. Wygłoszone i zapisane przez niego Kazanie pierwsze $w$ czasie nabożeństwa siedmiodniowego w kościele krakowskim S. Michała xx. Karmelitów Bosych miane ... ukazało się drukiem w 1784 roku, w oficynie Fortecy Najświętszej Maryi Panny w Berdyczowie ${ }^{73}$.

Przedstawiony szkicowo wkład polskich karmelitów bosych w szeroko pojętą kulturę piśmiennictwa teologiczno-filozoficznego, mistycznego i kaznodziejstwa nie wyczerpuje w całości poruszanej problematyki. Bez wątpienia, jeśli chodzi o piśmiennictwo polskie był to wkład znaczący, w którym bardzo wyraźnie przebija wydźwięk duchowości zakonnej, tak bardzo charakterystycznej dla karmelu bosego. Dzieła, których autorami byli pierwsi polscy karmelici bosi, w literaturze przedmiotu zwykło określać się mianem tzw. karmelitanów. Zachowane do czasów obecnych w bibliotece dawnego klasztoru-eremu w Czernej noszą widoczne ślady ich użytkowania w ciągu minionych wieków. Służyły one zakonnikom nade wszystko w procesie realizacji ich powołania zakonnego, a tym samym i pogłębianiu życia duchowego.

Słowa kluczowe: starodruki, karmelici bosi, Czerna, klasztor, biblioteka zakonna

\section{ANTIQUE BOOKS, SO-CALLED KARMELITANA IN THE COLLECTION OF THE MONASTIC LIBRARY IN CZERNA}

\section{Summary}

The monastery-hermitage of the Discalced Carmelites in Czerna, created in the seventeenth century, collected books related to the history and spirituality of the Carmelites, and the legislation of that Order from its inception. That was due to the fact that the Carmelites, especially in the seventeenth and eighteenth centuries, had a significant impact on the development of Marian, patristic and ascetic spirituality. Eminent people from the circle of Carmelite feathers left behind works that today inspire the development of spiritual and mystical theology. Carmelite literature focused primarily on four thematic groups: the theology of the inner life, the controversial theology, Mariology and broadly defined preaching. Concern for the last one was clearly visible in the pastoral activities of the Discalced Carmelites from the beginning of their presence in Poland. Numerous treaties, studies, Spanish translations of mystics' writings and sermons preserved in the library of Czerna are the sign of theological and preacher's activity of the Carmelites. Preserved to the present day in the library of the former monastery-hermitage of Czerna, they show the signs of use over the past centuries. They served the monks, above all in the pursuit of their religious vocation, and thus deepening their spiritual lives.

Keywords: antique books, the Discalced Carmelites, Czerna, monastery, monastic, library

${ }^{73}$ BKC, sygn. 432, poz. inw. 467. 